\title{
KONSELING KEAGAMAAN BAGI LANJUT USIA (LANSIA)
}

\author{
Dulhadi
}

\begin{abstract}
Abstrak
Secara alami, jika panjang umur, manusia pasti mengalami penuaan dan memasuki fase lansia. Sebagian lansia siap dengan fase ini bahkan sangat berbahagia dengannya. Namun sebagian ada yang tidak siap dan menderita karenanya. Ketidaksiapan ini dapat dimengerti karena ketika seseorang telah menapaki usia lanjut berbagai "kenikmatan" yang selama ini dia rasakan secara perlahan mulai menghilang.

Oleh sebab itu, tidak jarang ditemui seorang lansia kemudian menjadi merasa tidak berguna lagi yang berujung pada keputusasaan. Kondisi lansia yang seperti ini tentu tidak boleh dibiarkan. Mereka harus tetap bersemangat dalam menjalani hidup seperti apapun

kondisinya. Dan salah satu upaya agar mereka tetap bisa menikmati hidup di masa tuanya ini adalah dengan menghadirkan konseling keagamaan.
\end{abstract}

Kata kunci: konseling, keagamaan, dan lansia.

\section{A. Pendahuluan}

Jika hidup seseorang berjalan secara normal, mencapai usia rata-rata manusia umumnya, maka memasuki usia lanjut atau lanjut usia menjadi sebuah keniscayaan. Semua orang tentu menginginkan memiliki usia yang panjang, namun tentu pula tidak semua orang siap menghadapi masa usia lanjut.

Ketidaksiapan sebagian orang mengadapi dan menjalankan hidup dalam usia yang telah lanjut, dapat difahami, karena setelah seseorang memasuki usia lanjut ini ia akan mengalami berbagai penurunan dari segi fisik. Sejalan dengan penurunan tersebut, maka secara psikis terjadi berbagai perubahan pula. Perubahan-perubahan gejala psikis ini ikut mempengaruhi berbagai aspek kejiwaan yang terlihat dari pola tingkah laku yang diperlihatkannya. Rita Arkinson (dalam Jalaluddin: 2003) membagi tahap perkembangan menjadi delapan tahap, yaitu (1) tahun-tahun pertama, (2) tahun kedua, (3) tahun ketiga hingga tahun-tahun ke empat, (4) tahun ke enam hingga pubertas, (5) Adolesen, (6) kedewasaan awal, (7) kedewasaan menengah, (8) tahuntahun terakhir (usia lanjut). Dijelaskan oleh Rita, bahwa pembagian tahap-tahap ini didasarkan pada berbagai perubahan perkembangan baik fisik maupun psikis yang berbeda untuk setiap tahap perkembangannya pada sekitar tahap tersebut.

Terkait dengan tahap perkembangan terakhir sebagaimana tersebut di atas, yang diperkirakan ketika seseorang memasuki usia 65 tahun, maka ia akan menghadapi berbagai permasalahan. 
Permasalahan pertama adalah penurunan dan berkurangnya kemampuan fisik, menurunnya aktivitas, sering mengalami gangguan kesehatan, yang kesemuanya ini menyebabkan mereka kehilangan semangat. Pengaruh dari kondisi penurunan kemampuan fisik ini menyebabkan mereka yang berada pada usia lanjut merasa dirinya sudah tidak berharga atau kurang dihargai.

Masih menurut hasil penelitian Rita Arkinson yang dikutip oleh Jalaluddin (2003) ditemukan bahwa masalah utama yang dihadapi manusia usia lanjut adalah konflik batin antara keutuhan dan keputusasaan. Oleh karena itu, mereka cenderung mengingat sukses masa lalu sehingga umumnya mereka yang berada pada tingkat usia lanjut ini senang membantu para remaja yang aktif, terutama pada kegiatan-kegiatan yang bersifat keagamaan.

Oleh sebab itu pula dapat dimengerti bila kehidupan keagamaan seseorang yang telah lanjut usia umumnya mengalami peningkatan. Berdasarkan penelitian yang dilakukan oleh Robert $\mathrm{H}$. Thouless (1992) ditemukan bahwa pada umumnya manusia lanjut usia memiliki kecenderungan untuk menerima pendapat keagamaan dari orang lain. Lebih dari itu, mereka semakin menyadari akan realitas tentang kehidupan akhirat. Bahkan kesadaran tentang adanya realitas kehidupan akhirat, tumbuh hingga 100 persen.
Meningkatnya sikap keagamaan pada orang lanjut usia yang telah dikemukakan di atas memberikan gambaran yang lebih konkret tentang ciri-ciri keberagamaan mereka. Jalaluddin (2003) mengidentifikasi ciri-ciri keberagamaan lansia, di antaranya sebagaimana berikut:

1. Kehidupan keagamaan pada usia lanjut sudah mencapai tingkat kemantapan.

2. Meningkatnya kecenderungan untuk menerima pendapat keagamaan.

3. Mulai muncul pengakuan terhadap realitas tentang kehidupan akhirat secara lebih sungguh-sungguh.

4. Sikap keagamaan cenderung mengarah kepada kebutuhan saling cinta antar sesama manusia dan sifat-sifat luhur.

5. Timbul rasa takut kepada kematian yang meningkat sejalan dengan pertambahan usia lanjutnya.

6. Perasaan takut kepada kematian ini berdampak pada peningkatan pembentukan sikap keagamaan dan kepercayaan terhadap adanya kehidupan abadi (akhirat).

Munculnya perasaan-perasaan negatif seperti ini, tentu harus segera diatasi, sebab jika tidak, maka akan membuat mereka semakin tidak berdaya dan semakin mempercepat kerapuhan fisik mereka. Di sinilah letak pentingnya kehadiran seorang pembimbing rohani (konselor agama) bagi mereka. Kehadiran konselor agama bagi lansia, terutama yang 
menghuni panti sosial menjadi kebutuhan primer. Oleh karena itu, layanan konseling, khususnya konseling agama harus hadir mendampingi lansia untuk memberikan bimbingan dan tuntunan mereka menghadapi saat-saat kematian yang mungkin tidak lama lagi.

\section{B. Deskripsi tentang Lansia}

\section{Pengertian Lansia}

Lansia (lanjut usia) adalah periode penutup dalam rentang hidup seseorang. Masa ini dimulai dari umur 60 tahun sampai meninggal dunia. Lansia ditandai dengan adanya perubahan yang bersifat penurunan kondisi fisik, psikis, dan sosial yang saling berinteraksi satu sama lain. Menurut UU no. 4 tahun 1965 lansia adalah seseorang yang mencapai umur 55 tahun, tidak berdaya mencari nafkah sendiri untuk memenuhi kebutuhan seharihari dan menerima nakah dari orang lain (wahyudi dalam Nia Aprina 2014).

Prayitna (dalam Nia Aprina, 2014) mendefinisikan lansia sebagai orang yang mencapai usia 56 tahun ke atas, tidak mempunyai penghasilan dan tidak berdaya untuk mencari nafkah untuk memenuhi kebutuhan pokoknya seharihari. Menurut jalaluddin (2010) lansia adalah orang yang telah mencapai umur 65 tahun. Pada usia ini mereka mulai menghadapi banyak permasalahan. Permasalahan pertama adalah penurunan kemampuan fisik hingga kekuatan fisik berkurang, aktivitas menurun, sering mengalami gangguan kesehatan yang menyebabkan mereka kehilangan semangat.

\section{Batasan Umur Lansia}

Para ahli dan lembaga-lembaga resmi yang berwenang ternyata memliki pendapat yang berbeda tentang batasan umur lansia, terutama dalam menetapkan pada umur berapa seseorang itu dianggap telah memasuki usia lanjut. Nia Aprina (2014) dalam kutipannya mengklasifikasi usia lansia sebagaimana berikut:

a. Penggolongan lansia menurut Kementerian Kesehatan:

1. Kelompok lansia dini (55-64 tahun), merupakan kelompok yang baru memasuki lansia.

2. Kelompok lansia (65-70 tahun).

3. Kelompok lansia beresiko tinggi, yaitu lansia yang berumur 70 tahun ke atas.

b. Penggolongan lansia menurut Organisasi Kesehatan Dunia (WHO):

1. Usia pertengahan (middle age) 4559 tahun.

2. Lanjut usia (olderly) 60-74 tahun.

3. Lanjut usia tua (old) 75-90 tahun.

4. Lansia sangat tua (very old) di atas 90 tahun.

\section{Kondisi Fisik lansia}

Secara fisik lansia pasti mengalami penurunan yang signifikan. Seiring dengan semakin bertambahnya usia, maka kemampuan fisikpun akan semakin menurun. Sri Surini Pudjiastuti dan Budi 
Utomo (2003) mencoba menggambarkan secara komprehensif sisi-sisi fisik yang mengalami gangguan fungsi setelah seseorang memasuki usia lanjut. Menurut keduanya setidaknya ada tujuh gangguan fisik yang akan dirasakan oleh para lansia, yaitu:

a. Gangguan fungsi motorik.

b. Gangguan fungsi sensorik.

C. Gangguan fungsi sensomotorik.

d. Gangguan fungsi kognitif dan intrapersonal.

e. Gangguan fungsi interpersonal dan sosial.

f. Gangguan kemampuan fungsional.

g. Gangguan lingkungan aktifitas.

Fungsi motorik mengalami gangguan disebabkan adanya perubahan pada otot, yaitu terjadinya penurunan kekuatan dan kontraksi otot, elastisitas dan fleksibilitas otot, kecepatan waktu reaksi dan rileksasi, dan kinerja fungsional. Penurunan fungsi dan kekuatan otot sebagaimana di atas akan mengakibatkan pada:

a. Penurunan kemampuan mempertahankan keseimbangan tubuh.

b. Hambatan dalam gerak duduk ke berdiri.

c. Peningkatan resiko jatuh.

d. Penurunan kekuatan otot dasar panggul.

e. Perubahan postur tubuh.

Gangguan fungsi sensorik lansia mengakibatkan gangguan penerimaan informasi dari reseptor sensorik sehingga mengakibatkan penurunan kontrol motorik atau gangguan gerakan. Gejala gangguan sensorik yang sering timbul pada lansia adalah hilangnya perasaan jika dirangsang (anestesia), perasaan berlebihan jika dirangsang (hiperestesia), perasaan yang timbul tidak semestinya (paraestesia), nyeri, gangguan fungsi proprioseptif, seperti gangguan rasa gerak, getar, dan posisi.

Gangguan fungsi sensomotorik utama lansia adalah gangguan keseimbangan dan koordinasi. Keseimbangan dan koordinasi merupakan integrasi kerja berbagai otot termasuk fungsi sistem aferen dan eferen saraf. Penurunan koordinasi disebabkan oleh penurunan kekuatan otot, waktu reaksi menjadi lambat, hilangnya fleksibilitas, fostur yang jelek, dan gangguan keseimbangan.

Adapun gangguan kognitif dan intrapersonal dapat dilihat dengan jelas pada penurunan kemampuan memecahkan masalah, memori, perhatian dan bahasa. Gangguan kognitif ini mengakibatkan pada:

a. Memori panjang. Lansia akan mengalami kesulitan dalam mengungkapkan kembali cerita atau kejadian yang tidak begitu manarik perhatiannya. Dia juga akan kesulitan apabila melakukan pekerjaan yang membutuhkan ingatan yang kompleks atau rumit. Di samping itu, dia juga mengalami dalam menempatkan objek. 
b. Proses informasi. Lansia akan menjadi kesulitan dalam menerima informasi baru seperti TV dan film.

Selanjutnya banyak penelitian menunjukkan bahwa terdapat fungsi otak yang mengalami sedikit perubahan atau tidak mengalami perubahan dengan bertambahnya usia, misalnya menyimpan informasi. Dengan bertambahnya usia, didapatkan penurunan berlanjut dalam kecepatan belajar, memeroses informasi baru, dan bereaksi terhadap stimulus sederhana atau kompleks.

Kemampuan interpersonal merupakan kemampuan seseorang dalam berhubungan, berkomunikasi, dan berinteraksi dengan orang lain sebagai individu, kelompok atau masyarakat. Penuaan menyebabkan individu mengalami krisis yang disebut dengan istilah pertempuran dalam dua kondisi/situasi, yaitu menghadapi golongan muda dan tua. Keadaan itu sering menimbulkan stres dan kekhawatiran akan tersisih dan kurang dihargai.

Berbagai kemunduran fisik mengakibatkan kemunduran gerak fungsional baik kemampuan mobilitas atau perawatan diri. Kemunduran fungsi mobilitas meliputi penurunan kemampuan mobilitas di tempat tidur, berpindah, jalan/ambulasi, dan mobilitas dengan alat adaptasi. Kemunduran kemampuan perawatan diri meliputi penurunan kemampuan aktivitas makan, mandi, berpakaian, defekasi dan berkemih, merawat rambut, gigi, serta kumis dan kuku. Selain itu kemunduran juga terjadi pada kemampuan berkomunikasi seperti kemampuan menggunakan telepon, menulis surat, dan mengadakan transaksi bisnis.

Masih menurut Sri Surini Pudjiastuti dan Budi Utomo (2003) bahwa kemunduran gerak fungsional dapat dikelompokkan menjadi tiga tingkatan ketergantungan, yaitu:

a. Mandiri, yaitu lansia mampu melaksanakan tugas tanpa bantuan orang lain (bisa saja lansia tersebut membutuhkan alat adaptasi seperti alat bantu jalan, alat kerja, dan lain-lain).

b. Bergantung sebagian, yaitu lansia bisa melaksanakan tugas dengan beberapa bagian memerlukan bantuan orang lain.

c. Bergantung sepenuhnya, yaitu lansia tidak dapat sama sekali melakukan tugas tanpa bantuan orang lain.

Menurut Scheuder (dalam Sri Surini Pudjiastuti dan Budi Utomo: 2003) ketergantuan lansia secara praktis dibagi dalam tiga tingkatan, yaitu:

a. Ketergantungan mengurus pribadi, merupakan ketergantungan yang paling berat.

b. Ketergantungan domistik, golongan ini masih dapat melakukan perawatan pribadi, tetapi untuk memasak, mencuci pakaian, belanja, dan pekerjaan rumah lainnya harus dibantu.

c. Ketergantungan finansial dan sosial, golongan ini masih dapat aktif bekerja 
dan pergi ke luar rumah, mereka hanya membutuhkan bantuan keuangan.

Penurunan gerak dan fungsi lansia berdampak terhadap kemampuan beradaptasi dengan lingkungan aktivitasnya. Keterbatasan lansia dalam penyesuaian diri dengan lingkungan aktivitasnya menyebabkan masalah lingkungan aktivitas. Masalah lingkungan aktivitas ini meliputi lingkungan di dalam dan di luar rumah.

Masalah lingkungan aktivitas di dalam rumah meliputi kemampuan untuk beradaptasi dengan:

a. Desain alat rumah tangga untuk keperluan memasak, mencuci, menyetrika, dan letak telepon dan kotak obat.

b. Desain interior rumah meliputi tangga, lantai, pintu, kamar mandi, WC, washtafel, dan penerangan.

c. Desain mebel yang meliputi kursi, meja, dan tempat tidur.

Adapun masalah lingkungan aktivitas di luar rumah meliputi kemampuan beradaptasi dengan alat transportasi umum/mobil, berbelanja, bekerja, dan berkreasi. Masalah lain kemungkinan akan timbul pada lansia yang menggunakan alat bantu/adaptasi, seperti kursi roda, kruk, walker, tripot, tongkat, splint, dan prostese.

Perkembangan masa dewasa akhir atau usia lanjut membawa penurunan fisik yang lebih besar dibandingkan dengan periode-periode usia sebelumnya. Perubahan pada kondisi fisik lansia, sebagaimana digambarkan oleh $\mathrm{Nia}$ Aprina (2014) ditandai dengan:

a. Sistem peredaran darah, jantung orang yang lebih tua bekerja dengan lebih keras untuk memompa jumlah darah yang sama, sehingga menimbulkan peningkatan tekanan darah.

b. Keseimbangan, semakin tua seseorang semakin kurang keseimbangannya, sehingga mudah mengalami jatuh.

c. Kekuatan otot, berkurangnya kekuatan otot sangat tampak pada otot-otot tangan dan otot yang menopang tegaknya tubuh.

d. Kecepatan dalam bergerak, semakin tua seseorang apalagi sampai mencapai usia lanjut, maka kecapatan dan kelincahan akan melambat.

e. Canggung dan gemetaran, lansia cenderung menjadi canggung dan mudah gemetaran, sehingga menyebabkan sesuatu yang dibawa dan dipegangnya tertumpah dan jatuh. Lebih dari itu, para lansia cenderung dalam mengerjakan sesuatu dilakukan dengan tidak hatihati dan teratur.

f. Sistem sensori, sistem ini juga mengalami penurunan yang meliputi indra penglihatan, pendengaran, perasa, pembau, dan peraba. Kemampuan melihat dan mendengar berkurang dan kebanyakan para lansia memerlukan alat bantu pendengaran. Daya penciuman menjadi kurang tajam, karena pertumbuhan sel dalam hidung berhenti dan semakin lebatnya bulu rambut di 
lubang hidung. Daya perasa juga berkurang akibat semakin banyaknya tunas perasa yang terletak di lidah dan di permukaan bagian dalam pipi berhenti tumbuh karena bertambahnya usia. Kepekaan terhadap rasa pahit dan masam bertahan lebih lama dibandingkan kepekaan terhadap rasa manis dan asin.

g. Sistem visual, dengan semakin tua, semakin dibutuhkan cahaya untuk dapat melihat lebih jelas. Begitu pula dengan membaca semakin terasa sulit dan memerlukan lensa korektif.

h. Sistem pernapasan, meliputi fungsi paru-paru menurun akibat berkurangnya elastisitas serabut otot yang mempertahankan pipa kecil dalam paru-paru tetap terbuka. Penurunan fungsi ini akan lebih berat jika yang bersangkutan memiliki kebiasaan merokok dan kurang berolahraga.

i. Otak dan sistem saraf, menurunnya fungsi otak akan berakibat melemahnya daya ingat, sehingga para lansia sering mengalami lupa termasuk minum obat yang pada akhirnya akan menimbulkan penyakit atau memperparah penyakit yang sudah dideritanya.

j. Seksualitas, orang yang berusia lanjut masih tetap memiliki nafsu seksual seperti halnya orang muda. Perubahan kemampuan seksual pada lansia ditandai dengan datangnya masa klimakterium, yaitu pada saat fungsifungsi seksual telah menurun. Pada wanita datang bersamaan dengan meopause atau berhentinya haid, sedangkan pada laki-laki diperlukan waktu yang lama untuk dapat ereksi.

\section{Kondisi Psikologis Lansia}

Sejak manusia mencapai usia kedewasaan hingga ke usia 50 tahun, perkembangan fisik manusia boleh dikatakan tidak mengalami perubahan yang banyak. Barulah di atas usia 50 tahun mulai terjadi penurunan perkembangan yang drastis hingga mencapai usia lanjut. Oleh karena itu, umumnya garis perkembangan pada periode ini digambarkan dengan garis yang menurun. Periode ini disebut dengan periode regresi (penurunan).

Sejelan dengan penurunan tersebut, maka secara psikis terjadi berbagai perubahan pula. Menurut jalaluddin (2010), dengan mengutip beberapa penelitian yang pernah dilakukan oleh para psikolog, didapati beberapa kondisi psikologis yang umumnya terjadi pada lansia, antara lain:

a. Kehilangan semangat hidup.

b. Merasa tidak berharga dan kurang dihargai.

c. Merasa sudah tidak berguna lagi.

d. Terjadi konflik batin antara keutuhan dan keputusasaan.

e. Selalu dibayangi kesuksesan masa lalu.

Kartini Kartono (2000) juga memberikan gambaran tentang kondisi 
kejiwaan pada lanjut usia. Menurutnya, jika lansia tidak bisa menerima kondisi dirinya dengan baik, maka kemungkinan hal berikut ini akan terjadi, yaitu:

a. Mengalami kesulitan beradaptasi secara sehat dengan lingkungan.

b. Secara fisik akan tampak layu, sayu, dan lemas.

c. Muncul perasaan apatis.

d. Sering dilanda depresi.

e. Selalu merasa serba salah.

f. Gampang berputusasa.

g. Mudah tersinggung.

h. Gampang meledak-ledak dan ribut.

i. Sering dilanda kegelisahan dan cemas.

j. Perasaan dilematis antara pemenuhan kebutuhan dan tenaga yang masih dimiliki.

\section{Perkembangan}

\section{Keagamaan Lansia}

Robert H. Thouless (1992) mengatakan bahwa perkembangan kehidupan keagamaan pada usia lanjut berdasarkan penelitian psikologi agama ternyata meningkat. M. Argyle mengutip sejumlah penelitian yang dilakukan oleh Cavan yang mempelajari 1200 orang sampel berusia 60-100 tahun, menemukan bahwa secara jelas kecenderungan untuk menerima pendapat keagamaan yang semakin meningkat pada umur-umur ini. Sedangkan pengakuan terhadap realitas tentang kehidupan akhirat baru muncul sampai 100 persen setelah usia 90 tahun.

Lebih jauh Robert $\mathrm{H}$. Thouless menjelaskan peningkatan kehidupan keagamaan pada lansia penyebabnya adalah karena adanya penurunan kemampuan seksual. Menurut pendukung pendapat ini lansia mengalami prustasi di bidang seksual, sejalan dengan penurunan kemampuan fisik dan prustasi semacam ini dinilai sebagai satu-satunya faktor yang membentuk sikap keagamaan. Namun menurut Robert, pendapat ini terlalu berlebihan. Sebab, hasil penelitian menunjukkan bahwa meskipun kegiatan seksual secara biologis boleh jadi sudah tidak ada lagi pada lansia, namun kebutuhan untuk mencintai dan dicintai masih tetap ada pada usia setua itu.

William James (1958) juga memberikan penjelasan bahwa umur keagamaan yang sangat luar biasa tampaknya justru terdapat pada usia tua, ketika gejolak seksual sudah berakhir. Jalaluddin (2010) ketika mengomentari pendapat James di atas mengatakan bahwa pendapat William James tersebut sampai saat ini masih dijadikan rujukan dalam melihat korelasi antara kehidupan keagamaan seseorang dengan kehidupan seksualnya. Jika dihubungkan dengan kehidupan esoteris para tokoh agama, seperti biarawan/biarawati atapun para biksu, agaknya korelasi tersebut menampakkan hubungan yang positif.

Berbagai latar belakang yang menjadi penyebab kecenderungan sikap keagamaan pada manusia lanjut usia seperti dikemukakan di atas, akan memberikan gambaran yang lebih jelas 
tentang ciri-ciri utama keberagamaan mereka. Menurut Jalaluddin (2010) ciri-ciri keberagamaan lansia dapat diurai sebagaimana berikut ini.

a. Kehidupan keagamaan manusia lanjut usia sudah mencapai tingkat kemantapan.

b. Meningkatnya kecenderungan untuk menerima pendapat keagamaan yang berasal dari luar dirinya.

c. Mulai muncul pengakuan terhadap realitas tentang kehidupan akhir secara lebih sungguh-sungguh.

d. Sikap keagamaan cenderung mengarah kepada kebutuhan saling cinta antar-sesama manusia dan sifat-sifat luhur.

e. Timbul rasa takut kepada kematian.

\section{Kebutuhan Lansia}

Sebagaimana kelompok umur yang lain, kelompok umur lansia juga memiliki banyak kebutuhan, baik kebutuhan primer maupun skunder, baik kebutuhan yang bersifat fisik maupun psikis. Secara fisik, lansia juga masih membutuhkan makan dan minum, rumah tempat berlindung, pakaian, bahkan bagi yang sehat, masih perlu akan kebutuhan biologis.

Pemenuhan kebutuhan primer yang bersifat fisik di atas amat sangat diperlukan agar lansia tertap bisa mempertahankan kualitas hidupnya. Sri Surini Pudjiastuti dan Budi Utomo (2003) menyarankan agar lansia tetap mampu mempertahankan kualitas hidup, tetap aktif dan produktif, maka lansia membutuhkan kemudahan dalam beraktivitas, pemahaman tentang lingkungan beraktivitas, dan pelayanan kesehatan yang memadai.

Kemudahan dalam beraktivitas akan membantu lansia melakukan kegiatannya tanpa hambatan, menggunakan energi minimal, dan harus ada upaya agar ter-hindar dari cedera. Pemahaman lingkungan aktivitas akan membantu lansia dalam penyesuaian aktivitas individu di rumah ataupun aktivitas sosial di masyarakat. Dan pelayanan kesehatan yang memadai amat diperlukan sebab lansia sangat rentan terhadap penyakit dan cedera.

Melihat keragaman masalah kesehatan pada lansia, upaya pencegahan harus diutamakan. Masalah kesehatan lansia tidak terjadi seketika itu saja, tetapi melalui proses kemunduran yang panjang. Proses itu dapat dihambat atau dalam beberapa hal tertentu dapat dicegah bila upaya pencegahan dilakukan sejak dini, terpadu, terus-menerus, dan berkesinambungan. Pertimbangan lain adalah tingginya biaya pelayanan kesehatan sehingga upaya pencegahan akan jauh lebih hemat dan murah dari pada upaya pengobatan.

Secara psikologis, lansia perlu perhatian secara khusus. Lansia juga butuh belaian dan kasih sayang, layaknya masa kanak-kanak. Secara psikologis, lansia sangat sensitif dan mudah tersinggung. Oleh karena itu, ucapan yang disampaikan kepada mereka haruslah 
kata-kata yang lemah lembut dan penuh dengan kesopanan.

\section{Perlakuan terhadap Lansia Menurut Islam}

Manusia usia lanjut dalam penilaian banyak orang adalah manusia yang sudah tidak produktif lagi. Kondisi fisik rata-rata sudah menurun, sehingga dalam kondisi yang sudah uzur ini berbagai penyakit siap untuk menggerogoti mereka. Dengan demikian di usia lanjut ini terkadang muncul semacam pemikiran bahwa mereka berada pada sisa-sisa umur dan hanya menunggu kematian saja. Dengan begitu pula, terkadang muncul gejolak batin yang sulit untuk diatasi oleh mereka sendiri. Jika tidak dapat di atasi, bukan tidak mungkin akan muncul tekanan batin dan gangguan jiwa lainnya seperti stress, putus asa, dan pada akhirnya mereka akan mengasingkan diri sebagai wujud dari rasa rendah diri.

Dalam kondisi sebagaimana di atas, menurut Jalaluddin (2010) agama dapat difungsikan dan diperankan sebagai penyelamat. Sebab, melalui pengamalan ajaran agama, lansia merasa memperoleh tempat bergantung. Menurut ajaran agama, perlakuan terhadap lansia harus dilakukan dengan seteliti dan setelaten mungkin.

Perawatan terhadap lansia sejatinya dilakukan oleh anak-anak, bukan kepada badan atau panti asuhan, termasuk panti jompo. Perlakukan terhadap orang- tua menurut tuntunan Islam, berawal dari rumah tangga. Allah menyebutkan pemeliharaan secara khusus orangtua yang telah lanjut usia dengan memerintahkan kepada anak-anak mereka untuk memperlakukan anak-anak mereka dengan penuh kasih sayang. Sebagaimana firman Allah, yang artinya:

"Jika salah seorang di antara
kedua atau kedua-duanya sampai
berumur lanjut dalam
pemeliharaanmu, maka sekali-kali
janganlah kamu mengatakan
kepada keduanya perkataan "ah"
dan janganlah kamu membentak
mereka dan ucapkanlah kepada
mereka perkataan yang
mulia"(QS. Al-Isra': 23)

Thoha Abdullah Al-Afifi ketika menafsirkan kata "uff"dalam ayat di atas mengatakan bahwa perkataan itu biasanya diucapkan bagi sesuatu yang ditolak. Menurutnya, jika ada perkataan yang lebih buruk dari kata uff itu tentulah Allah akan menyebutkannya. Oleh karena itu, perkataan uff untuk kedua orang tua adalah perkataan yang paling buruk.

Al-Qur'an telah memberikan tuntunan kepada umat manusia bagaimana seharusnya mereka memperlakukan orangtua, sebagaimana firman-Nya, yang artinya:

"Dan rendahkanlah dirimu terhadap mereka berdua dengan penuh kesayangan dan ucapkanlah: "Wahai Tuhanku, kasihilah mereka berdua, sebagaimana mereka berdua telah 
mengasihi dan mendidikku sejak aku masih kecil" (QS. Al-Isra': 24)

Menurut ibnu Jarir dan Ibnu Munzir yang dimaksud dengan rendahkanlah dirimu terhadap mereka berdua dengan penuh kesayangan adalah tunduk kepada kedua orangtua sebagaimana tunduknya kepada tuannya yang bengis dan keras. Pengertian ini memberikan kiasan bagaimana seharusnya seorang anak bersikap di hadapan orangtua (Thoha Abdullah AlAfifi; 1987).

Sebagai gambaran tentang hal itu adalah pernyataan Aisyah ra tentang bagaimana perilaku anak kepada orangtua, adalah dialog Rasulullah dengan seorang laki-laki. Rasulullah bertanya: "siapakah yang bersamamu?" Laki-laki itu menjawab: "ayahku". Beliau berkata: "jangan berjalan di depannya dan jangan duduk sebelum dia, jangan memanggilnya dengan namanya dan jangan berbuat sesuatu yang menyebabkan orang lain memakinya".

Perlakuan kepada orangtua dengan baik dikaitkan sebagai kewajiban agama. Menurut Ibnu Abbas, Rasulullah bersabda:

"Barang siapa membuat ridha kedua orangtuanya di waktu pagi dan sore, maka iapun mendapat dua pintu surga yang terbuka, dan jika membuat ridha salah satu di antaranya, maka akan terbuka satu pintu surga. Barangsiapa pada waktu pagi dan sore membuat amarah orangtuanya, maka ia akan mendapat dua pintu neraka yang terbuka, dan jika ia membuat marah salah satunya, maka tebuka satu pintu neraka untuknya".

Dalam subuah hadits yang sangat populer dinyatakan oleh Rasulullah, sebagaimana sabdanya: "Ridha Allah tergantung kepada ridha orangtunya dan kemurkaan Allah tergantung kepada kemurkaan orangtuanya"

Islam mengajarkan bahwa dalam perkembangannya, manusia mengalami penurunan kemampuan sejalan dengan pertambahan usia mereka. Sebagaimana firman-Nya:

\section{"Barangsiapa kami panjangkan umurnya niscaya kami kembalikan ia kepada kejadian (nya), maka apakah mereka tidak memikirkannya" (QS. 36: 68).}

Dari penjelasan di atas tergambar bagaimana perlakukan terhadap manusia lanjut usia menurut Islam. Lansia dipandang tak ubahnya seorang bayi yang memerlukan pemeliharaan dan perawatan serta perhatian khusus dengan penuh kasih sayang. Perlakuan yang demikian itu tidak dapat diwakilkan kepada siapapun, melainkan menjadi tanggung jawab anakanak mereka. Perlakuan yang baik dan penuh kesabaran serta kasih sayang dinilai sebagai kebaikan. Sebaliknya, perlakuan tercela dinilai sebagai sebuah kedurhakaan.

Penjelasan ini menunjukkan bahwa perlakuan terhadap manusia usia lanjut 
menurut Islam merupakan kewajiban agama, maka sangat tercela dan dipandang durhaka apabila seorang anak tega menempatkan orangtuanya di tempat penampungan atau panti jompo. Alasan apapun tidak bisa diterima bagi perlakuan seperti itu.

\section{Problem Keagamaan Lansia}

Pada dasarnya problem keagamaan yang dihadapi manusia di segala tingkatan usianya tidaklah jauh berbeda. Artinya apa yang menjadi problem lansia bisa juga menjadi problem bagi anak muda. Begitu juga sebaliknya. Menurut Aunur Rahim Faqih (1994), problem-problem keagmaan manusia dapat dirinci sebagai berikut:

1. Problem ketidakberagamaan; artinya seseorang atau kelompok individu tidak atau belum beragama dan berkehendak untuk beragama, merasakan kesulitan untuk memeluk atau menganut suatu agama disebabkan belum mampu meyakinkan diri tentang agama mana yang paling tepat bagi dirinya untuk dianut.

2. Problem pemilihan agama; artinya seseorang atau sekelompok individu yang belum menganut agama dan berkehendak untuk beragama merasa kesulitan dalam memilih suatu agama tertentu untuk dianut.

3. Problem kegoyahan iman; artinya seseorang atau sekelompok individu yang senantiasa goyah dalam keimanannya, sehingga ada kecenderungan di suatu saat untuk mengikuti agama yang satu, dan pada kali lain berkeinginan untuk mengikuti agama yang lain lagi.

4. Problem karena perbedaan faham dan pandangan; artinya seseorang atau sekelompok individu menderita konflik batin karena mendapatkan informasi yang bertentangan mengenai keimanan dan/atau ubudiyah yang menyebabkannya sulit untuk melakukan suatu tindakan atau perbuatan.

5. Problem ketidakfahaman mengenai ajaran agama; artinya seseorang atau sekelompok individu melakukan seautu tindakan atau perbuatan yang disadari atau tidak merugikan dirinya sendiri dan/atau orang lain, karena tidak memahami secara penuh ajaran agama.

6. Problem pelaksanaan ajaran agama; artinya seseorang atau sekelompok individu tidak mampu menjalankan ajaran agama sebagaimana mestinya karena adanya berbaagai sebab.

\section{E. Konseling Keagamaan (Islam) bagi Lansia}

Konseling keagamaan dapat didefinisikan sebagai proses pemberian bantuan kepada individu agar menyadari kembali eksistensinya sebagai makhluk Allah yang seharusnya dalam kehidupan keagamaannya senantiasa selaras dengan ketentuan dan petunjuk Allah sehingga dapat mencapai kebahagiaan hidup di 
dunia dan akhirat (Aunur Rahim Faqih: 1994).

Sebagaimana dimaklumi bahwa konseling adalah upaya yang penekanannya pada usaha kuratif atau pemecahan masalah yang dihadapi seseorang. Secara Islami, konseling keagamaan dapat dijadikan media untuk membantu seseorang menyadari kembali keberadaannya di dunia ini sebagai makhluk Allah, sebagai ciptaan-Nya untuk senantiasa mengabdi kepada-Nya sesuai dengan petunjuk dan ketentuan-Nya. Menyadari eksistensinya sebagai makhluk Allah sesuai dengan ketentuan-Nya, berarti menyadari bahwa di dalam dirinya Allah telah menyertakan fitrah untuk beragama Islam dan menjalankannya dengan sebaik-baiknya.

Dengan demikian, permasalahan keagamaan apapun senantiasa akan dikembalikan kepada petunjuk Allah. Oleh karena itu, konseling keagamaan memiliki tujuan yang sangat mulia yaitu:

1. Membantu individu mencegah timbulnya masalah-masalah dalam kehidupan keagamaan, antara lain dengan cara:

a. Membantu individu menyadari fitrahnya sebagai manusia.

b. Membantu individu mengembangkan fitrahnya sehingga bisa mengaktualisasikan dirinya.

c. Membantu individu memahami dan menghayati ketentuan dan petunjuk Allah dalam kehidupan keagamaan. d. Membantu individu menjalankan ketentuan dan petunjuk Allah mengenai kehidupan keagamaan.

2. Membantu individu memecahkan masalah yang berkaitan dengan kehidupan keagamaannya, antara lain dengan cara:

a. Membantu individu memahami problem yang dihadapinya.

b. Membantu individu memahami kondisi dan situasi diri dan lingkungannya.

c. Membantu individu memahami dan menghayati berbagai cara untuk mengatasi problem kehidupan keagamaannya sesuai dengan syari'at Islam.

d. Membantu individu menetapkan pilihan upaya pemecahan problem keagamaan yang dihadapinya.

3. Membantu individu memelihara situasi dan kondisi kehidupan keagamaan dirinya yang telah baik agar tetap baik dan/atau menjadi lebih baik.

Oleh sebab itu, menurut Aunur Rahim Faqih (1994) yang menjadi subjek atau pihak yang mendapat konseling (klien) dari konseling keagamaan ini adalah:

1. Individu/kelompok individu yang tidak beragama dan belum meyakini akan perlunya agama.

2. Individu/kelompok individu yang tidak atau belum beragama dan bermaksud beragama, tetapi belum mempunyai 
keyakinan yang pasti untuk menganut agama yang mana.

3. Individu/kelompok individu yang senantiasa goyah keimanannya, sehingga terlalu mudah untuk bergantiganti agama.

4. Individu/kelompok individu yang menghadapi konflik keagamaan karena memperoleh informasi yang berbeda mengenai ajaran agama.

5. Individu/kelompok individu kurang pemahamannya mengenai ajaran agama sehingga melakukan tindakan atau perbuatan yang tidak semestinya menurut syari'at Islam.

6. Individu/kelompok individu yang tidak/belum menjalankan ajaran agama sebagaimana mestinya.

\section{Hamdani Bakran Azdz-Dzaky}

(2006) mengungkapkan tentang langkahlangkah yang bisa ditempuh seorang konselor agama dalam memberi konseling kepada kliennya. Tentu saja langkah ini bisa diberikan setelah konselor melakukan identifikasi problem klien secara mendalam.

1. Memberikan nasehat, wejangan, himbauan dan ajakan yang baik dan benar. Dalam konseling, konselor lebih banyak menggunakan lisan, yaitu berupa pertanyaan-pertanyaan yang harus dijawab oleh klien dengan baik, jujur, dan benar. Agar konselor dapat mendapatkan jawaban-jawaban dan pertanyaan-pertanyaan yang jujur dan terbuka dari klien, maka kalimat-kalimat yang dilontarkan konselor harus berupa kata-kata yang mudah difahami, sopan dan tidak menyinggung atau melukai hati dan perasaan klien. Demikian pula ketika memberikan nasehat atau pandangan positif tentang hal-hal yang harus direnungkan oleh klien, hendaknya dilakukan dengan kalimatkalimat yang indah, bersahabat, menenangkan dan menyenangkan.

2. Membacakan do'a untuk klien. Untuk memantapkan klien, maka do'a yang diucapkan konselor harus didengar oleh klien atau jiwanya menjadi tenang dan turut mengucapkan kata "amin". Teknik ini dapat dilakukan konselor pada konseling yang bersifat kelompok. Teknik ini juga sangat besar manfaatnya bagi klien, karena do'a dapat menimbulkan optimisme dan ketentraman jiwa.

Sementara itu Kartini Kartono (2000) memberikan saran, agar para lansia tetap memiliki jiwa yang sehat dan tegar, maka para lansia harus:

1. Mau menerima kondisi diri apa adanya.

2. Usia tua harus disikapi sebagai sebuah keniscayaan dan harus dianggap sebagai pengalaman baru.

3. Segala kebahagiaan dan puncak kehidupan yang sudah digariskan oleh Tuhan Yang Maha Kuasa, juga semua ujian dan duka nestapa sudah dilalui dengan pasrah hati. Namun perjalanan hidup seterusnya masih harus dilanjutkan dengan ketabahan dan 
tawakal. Sebab pada masa usia tua ini masih saja ada misi-misi hidup yang harus diselesaikan sampai tuntas; di samping harus memberikan kebaikan dan kecintaan kepada lingkungan sekitar, misalnya berbuat kebaikan kepada anak-istri, cucu-cucu, para tetangga, generasi penerus, masyarakat sekitar, dan lain-lain.

4. Usia tua harus diterima dengan kemantapan hati sebagai karunia dari Tuhan Yang Maha Kuasa.

5. Pada usia tua ini, lansia harus lebih sabar dan tidak lagi bermimpi melakukan hal-hal yang luar kemampuannya, walaupun harus tetap berniat untuk selalu berbuat baik.

6. Tidak lagi melakukan perbandingan antara masa jayanya dulu dengan kondisi barunya yang sekarang. Sebab hal itu hanya akan membuat dirinya sedih dan kecewa.

7. Setiap hari lansia harus merasa semurni, seindah dan seringan bayi yang baru lahir dan dilahirkan kembali di dunia dalam kedamaian spritual. Segala masalah hidup akan dihadapi dengan hati yang lepas gembira.

8. Lansia harus bisa membebaskan diri dari segala hawa nafsu, ambisi, dan keinginan berkuasa, serta nafsu untuk memiliki. Apa yang didambakan dalam usia yang seperti ini semestinya sesuatu yang bisa menghadirkan ketenangan, kedamaian dan kesejukan hati.
9. Lansia harus mampu membebaskan diri dari segala bentuk ambivalensi (kemajemukan).

10. Lansia harus menghadapi hidup ini dengan penuh senyuman dan keberanian menghadapi masa akhir hayat.

\section{F. Penutup}

Menjadi tua adalah sebuah keniscayaan. Semua kita harus siap menghadapinya dengan kegembiraan dan senyuman. Namun menyambut hari tua dengan kegembiraan dan senyuman, tidak semua orang dapat melakukannya. Untuk bisa melakukannya, sesorang harus menyadari bahwa hidup ini bukanlah seperti bulatan bola, tetapi bagaikan garis lurus yang tidak akan pernah kembali lagi ke titik awal. Oleh karena itu, kesadaran seperti ini harus ditanamkan kepada setiap orang lebih-lebih kepada mereka yang telah berusia senja. Salah satu cara menanamkan kesadaran seperti ini adalah dengan menghadirkan konseling keagamaan.

\section{G. Daftar Pustaka}

Aunur Rahim Faqih, (2001), Bimbingan dan Konseling dalam Islam, UUI Press: Jogjakarta.

Bogdan, Robert, \& Taylor, J. Steven, (1992), Pengantar Metode Penelitian Kualitatif: Suatu Pendekatan Fenomenologi terhadap IImu-ilmu Sosial, 
(Terjemahan Arief Furchan),

Usaha Nasional: Surabaya.

Departemen Agama, (2013), Al-Qur'an

dan Terjemahannya, Yayasan

Penyelenggara/Penafsir Al-

Qur'an, Lajnah Penafsir Mushaf

Al-Qur'an, Kementerian Agama

RI.

Hamdani Bakran Adz-Dzaky, 2006,

Konseling dan Psikoterapi Islam,

Fajar Pustaka Baru, Jokjakarta.

Harun Rasyid, (2000), Metodologi

Penelitian Kualitatif Bidang

Sosial dan Agama, BMT STAIN:

Pontianak.

lin Tri Rahayu, (2009), Psikoterapi

(perspektif Islam dan Psikologi

Kontemporer), UIN Malang

Press: Malang.

James, Willian, (1958), The Varieties of

Religious Experience, New York, AS.

Jalaluddin, 2000, Psikologi Agama, PT.

RajaGrafindo Persada: Jakarta.
Jalaluddin Rakhmat, (2000), Psikologi

Sosial, Remaja Rosdakarya:

Jakarta.

Kartini Kartono, (2000), Hygiene Mental, Mandar maju: Bandung.

Muhammad Utsman Najati, (2004), Psikologi dalam Perspektif Hadits, Pustaka Al-Husna Baru: Jakarta.

Nia Aprina, 2014, Bimbingan Praktik Shalat pada Orang Lanjut Usia di UPT Panti Sosial Tresna Wedha Mulia Dharma Kecamatan Sungai Raya Kabupaten Kubu Raya, STAIN Pontianak.

Sri Surini Pudjiastuti dan Budi Utomo, (2013), Fisioterapi pada Lansia, Penerbit Buku Kedokteran EGC: Jakarta.

Thoha Abdullah Al-Afifgi (1987), Hak Orangtua pada Anak dan Hak Anak pada Orangtua, Dar El Fikr: Jakarta.

Thouless, Robert H, 1992, Pengantar Psikologi Agama, Terj. Machnun Husein, Rajawali: Jakarta. 